\title{
Modified Cap Group Suberoylanilide Hydroxamic Acid Histone Deacetylase Inhibitor Derivatives Reveal Improved Selective Antileukemic Activity
}

\author{
Chanaz Salmi-Smail,${ }^{\dagger}$ Aurélie Fabre, ${ }^{\dagger}$ Franck Dequiedt, ${ }^{\star}$ Audrey Restouin,${ }^{\dagger}$ Rémy Castellano, ${ }^{\dagger}$ Slaveia Garbit,${ }^{\dagger}$ \\ Philippe Roche, ${ }^{\S}$ Xavier Morelli, ${ }^{\S}$ Jean Michel Brunel, ${ }^{*, l}, \perp$ and Yves Collette ${ }^{\dagger, \perp}$ \\ ${ }^{\dagger}$ Unité 891 INSERM, Centre de Recherche en Cancérologie de Marseille, 27 bd Lei Roure, 13009 Marseille 09, France, ${ }^{\star}$ Cellular and Molecular \\ Biology Unit, Fonds National de la Recherche Scientifique, Faculté Universitaire des Sciences Agronomiques de Gembloux, 13 Av. Maréchal Juin, \\ B-5030 Gembloux, Belgium, ${ }^{\S}$ CNRS-IBSM, IMR Laboratory, 31 Chemin de Joseph Aiguier, 13402 Marseille 20, France, and "Laboratoire \\ URMITE UMR 6236 CNRS, Faculté de Médecine et de Pharmacie, Université de la Méditerranée, 27 bd Jean Moulin, 13385 Marseille 05, \\ France. ${ }^{\perp}$ J.M.B. and Y.C. share senior coauthorship.
}

Received September 16, 2009

\begin{abstract}
A series of SAHA cap derivatives was designed and prepared in good-to-excellent yields that varied from $49 \%$ to $95 \%$. These derivatives were evaluated for their antiproliferative activity in several human cancer cell lines. Antiproliferative activity was observed for concentrations varying from 0.12 to $>100$ $\mu \mathrm{M}$, and a molecular modeling approach of selected SAHA derivatives, based on available structural information of human HDAC8 in complex with SAHA, was performed. Strikingly, two compounds displayed up to 10 -fold improved antileukemic activity with respect to SAHA; however, these compounds displayed antiproliferative activity similar to SAHA when assayed against solid tumorderived cell lines. A 10-fold improvement in the leukemic vs peripheral blood mononuclear cell therapeutic ratio, with no evident in vivo toxicity toward blood cells, was also observed. The hereindescribed compounds and method of synthesis will provide invaluable tools to investigate the molecular mechanism responsible for the reported selectively improved antileukemic activity.
\end{abstract}

\section{Introduction}

The reversible acetylation of lysine residues in histone tails plays a critical role in transcriptional activation and repression. ${ }^{1,2}$ The regulation of these post-translational modifications is balanced by opposing histone acetyltransferase $\left(\mathrm{HAT}^{a}\right)$ and histone deacetylase (HDAC) activities. Increased HDAC activity has generally been associated with transcriptional repression, whereas increased HAT activity (or HDAC inhibition) facilitates gene expression. ${ }^{1,2}$ HDACs are also involved in reversible acetylation of non-histone proteins. ${ }^{3-5}$ There are around 20 human HDACs that fall into four classes ${ }^{6,7}$ based on their homology to yeast models: class I and II are zinc-dependent metallohydrolases, ${ }^{6}$ whereas class III HDACs or sirtuins are $\mathrm{NAD}^{+}$-dependent deacetylases. ${ }^{8}$ Class IV, recently described (comprising only HDAC11), exhibits properties of both class I and class II HDACs. Treatment of tumor cells with general inhibitors of class I/II HDACs results in growth arrest, differentiation, and apoptosis, ${ }^{1-11}$ promoting these enzymes as potential cancer drug targets. ${ }^{12}$

In this context, numerous programs involving short chain fatty acids (butyrate and valproate derivatives), cyclic peptides, depsipeptide (FK-228), and hydroxamic acid deriva-

*To whom correspondence should be addressed. Phone: (33) 4-86-1368-30. Fax: (33) 4913877 72. E-mail: bruneljm@yahoo.fr; yves.collette@ inserm.fr.

${ }^{a}$ Abbreviations: SAHA, suberoylanilide hydroxamic acid; HDAC, histone deacetylase; HAT, histone acetyltransferase; HDLP, histonedeacetylase-like protein; HDAH, histone-deacetylase-like amidohydrolase; BOP, benzotriazol-1-yloxytris(dimethylamino)phosphonium hexafluorophosphate.

pubs.acs.org/jmc

Published on Web 03/10/2010
Scheme 1. Structure of SAHA

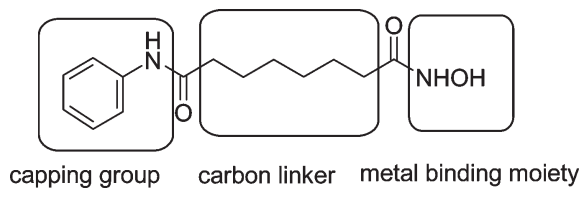

tives are in both preclinical development and clinical trials. ${ }^{13}$ Among all of these inhibitors, suberoyl anilide hydroxamic acid (SAHA, 1a) ${ }^{14}$ has emerged as an effective therapeutic anticancer agent and recently gained FDA approval for the treatment of advanced cutaneous T-cell lymphoma. ${ }^{15}$ Most HDAC inhibitors synthesized to date closely resemble the aliphatic acetyl-lysine substrate. These deliver an hydroxamic acid or other zinc-binding group to the catalytic zinc ion at the bottom of a narrow active site pocket, as seen in cocrystal structures of inhibited HDLP (HDAC-like protein), ${ }^{16} \mathrm{HDAH}$ (HDAC-like amidohydrolase), ${ }^{17}$ and human HDAC8. ${ }^{18}$ In addition to altering the metal-binding moiety toward a HDAC inhibitor design, the hydrocarbon linker has been diversified to focus on changing chain length, the creation of unsaturation points along the chain, and the inclusion of an arylcyclohexyl ring within the chain. ${ }^{19-22}$ Thus, distinguishing characteristics of HDAC inhibitors like SAHA have included a metal binding moiety, carbon linker, and capping group (Scheme 1).

On the basis of crystallographic analyses, the capping group is solvent-exposed and interacts with amino acids near the entrance of the active site. In contrast, the metal-binding moiety resides in the protein interior and complexes with the 
Scheme 2. General Pathway for SAHA Parent Derivative Synthesis

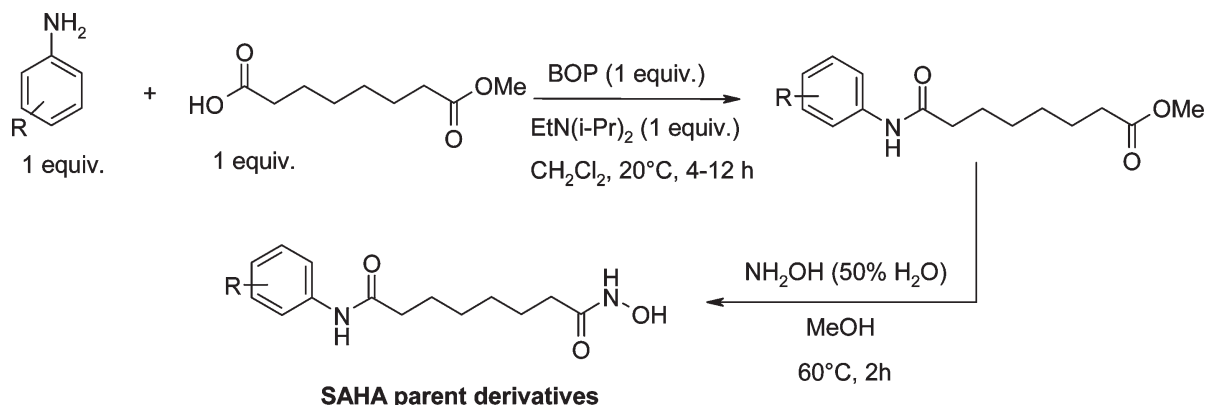

Table 1. Yields and $\log D$ of New Synthesized SAHA Analogues $\mathbf{1 a}-\mathbf{v}$<smiles>O=C(CCCCCCC(=O)Nc1ccccc1)NO</smiles>

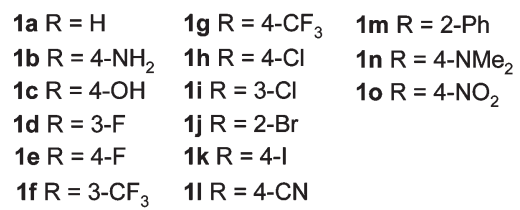<smiles>O=C(O)CCCCCCC(=O)NO</smiles><smiles>[R]NC(=O)CCCCCCC(=O)NO</smiles><smiles>Cc1ccc2c(c1)Cc1ccc([In][Tl])cc1-2</smiles><smiles>Cc1cccc2cccnc12</smiles><smiles>Cc1cc2ccc3cccc4ccc(c1)c2c34</smiles>

1t $\mathrm{R}^{\prime}=\mathrm{OH}$

\begin{tabular}{|c|c|c|c|c|c|c|c|c|}
\hline \multirow[b]{2}{*}{ compd } & \multirow[b]{2}{*}{ yield $(\%)^{a}$} & \multirow[b]{2}{*}{$\log D^{b}$} & \multicolumn{6}{|c|}{$\mathrm{EC}_{50}(\mu \mathrm{M})^{c}$} \\
\hline & & & Skbr3 & HT29 & U937 & JA16 & HL60 & K562 \\
\hline $1 \mathrm{a}$ & 79 & 1.67 & 2.1 & 2 & 0.82 & 0.87 & 1.2 & 2.2 \\
\hline $1 \mathrm{~b}$ & 67 & 0.88 & 8.5 & 18 & 6.4 & & & \\
\hline $1 \mathrm{c}$ & 91 & 1.38 & 11 & 15 & 6.4 & & & \\
\hline 1d & 91 & 1.81 & 1.9 & 1.4 & 0.5 & 0.64 & 1.25 & 2.4 \\
\hline 1e & 84 & 1.81 & 3 & 4.2 & 1.8 & & & \\
\hline 1f & 75 & 2.56 & 26 & 6.4 & 1.2 & & & \\
\hline $1 \mathrm{~g}$ & 95 & 2.56 & 2.2 & 1.4 & 0.45 & 0.53 & 1.54 & 2,1 \\
\hline $1 \mathrm{~h}$ & 88 & 2.19 & 2.3 & 2.1 & 0.55 & 0.77 & 1.87 & 3.3 \\
\hline $1 \mathrm{i}$ & 89 & 2.19 & 2 & 1 & 0.35 & 0.58 & 2.1 & 3.5 \\
\hline $1 \mathrm{j}$ & 82 & 1.82 & 17.5 & 17 & 6.8 & & & \\
\hline $1 \mathrm{k}$ & 90 & 2.66 & 1.1 & 0.95 & 0.12 & 0.24 & 0.85 & 1.3 \\
\hline 11 & 89 & 2.66 & 8.8 & 42 & 7 & & & \\
\hline $1 \mathrm{~m}$ & 77 & 3.32 & 73.5 & 27 & 14 & & & \\
\hline 1n & 92 & 1.93 & 4.2 & 3.15 & 1.7 & & & \\
\hline 10 & 92 & 1.63 & 58 & 76 & 22 & & & \\
\hline $1 p$ & 84 & 2.68 & 1.8 & 0.85 & 0.35 & 0.4 & 1.16 & 3 \\
\hline $1 q$ & 49 & 1.75 & $>100$ & $>100$ & 26 & & & \\
\hline $1 \mathrm{r}$ & 91 & 3.39 & 4 & 2.5 & 0.6 & 0.43 & 1.13 & 3.5 \\
\hline $1 \mathrm{~s}$ & 77 & 4.00 & 1.2 & 1.4 & 0.3 & 0.18 & 0.35 & 0.8 \\
\hline $1 t$ & 94 & -0.93 & 27 & 32 & 23 & & & \\
\hline $1 u$ & 49 & -2.73 & $>100$ & $>100$ & $>100$ & $>100$ & $>100$ & $>100$ \\
\hline $1 v$ & 89 & -0.92 & 40.5 & 63 & 26.5 & 16 & 18 & $>100$ \\
\hline
\end{tabular}

${ }^{a}$ Overall yield after two-step synthesis. ${ }^{b}$ The $\log D$ value has been estimated using Marvin software. ${ }^{c} \mathrm{EC}_{50}$ (half maximal effective concentration) refers to the concentration of a drug inducing a response halfway between the baseline and maximum after a specified exposure time.

metal ion involved in catalysis. ${ }^{16,18,32}$ However, the influence of substitution of the phenyl SAHA capping group remains unclear. This area of study remains relatively unexplored, most likely because the paths of synthesis described thus far have precluded such analogues from being easily produced. To the best of our knowledge, the four SAHA synthetic procedures described to date suffer from low yields and/or long reaction times (up to $28 \mathrm{~h}$ for the first three). ${ }^{23-25}$ On the other hand, Gediya et al. ${ }^{26}$ have reported an interesting expeditious SAHA synthetic route. However, no extension of such a procedure for the design of various SAHA derivatives has been envisioned, and no evaluation of their potent biological activities has been described. It is noteworthy that several unpublished variations of the SAHA structure seem to 


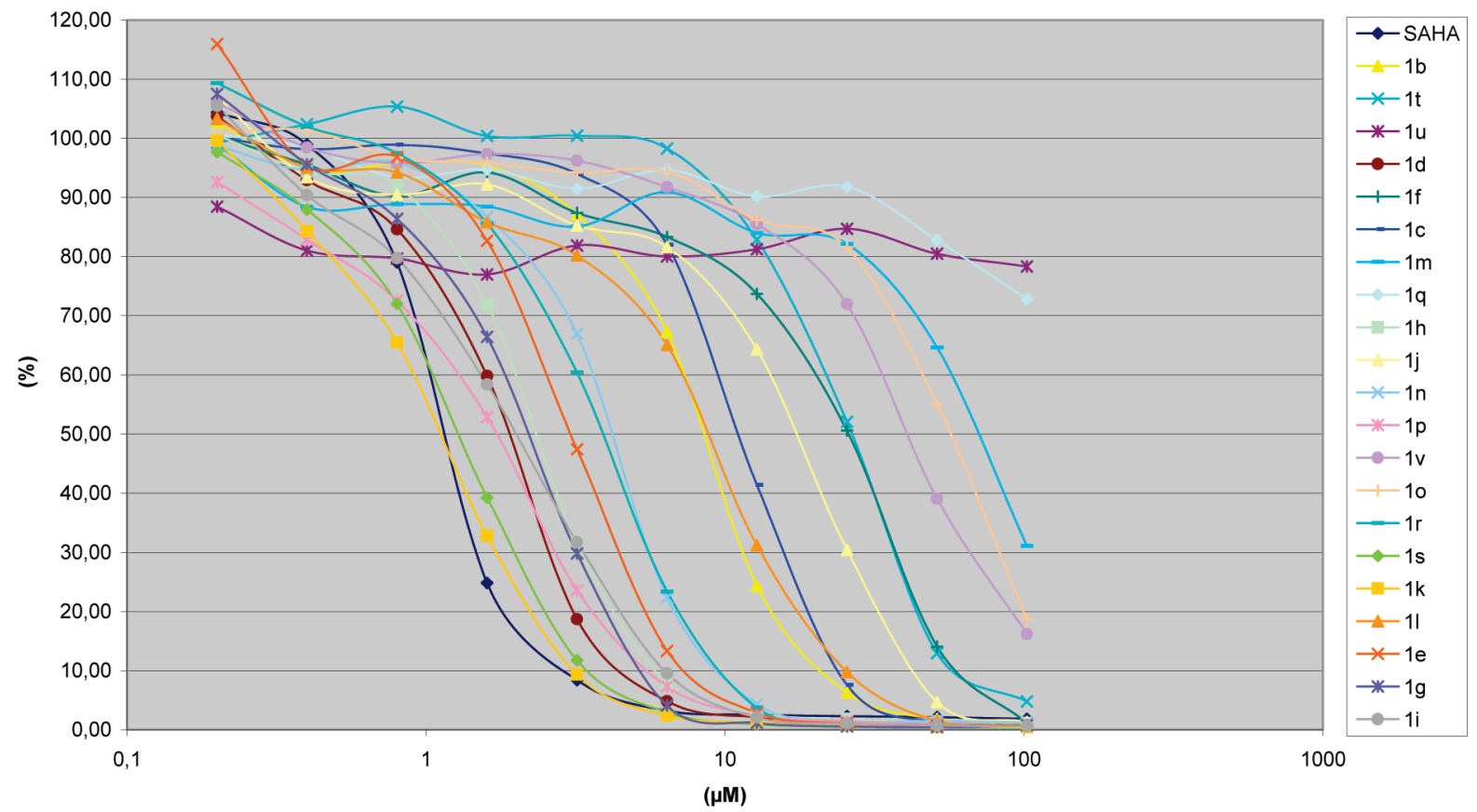

Figure 1. Dose-response antiproliferative activity of compounds 1a (SAHA) to 1v in breast-derived SkbR3 cells for the indicated range of concentrations $(0.1-100 \mu \mathrm{M})$. Results are expressed as the percent proliferative response after normalization to solvent (DMSO) treated cells.
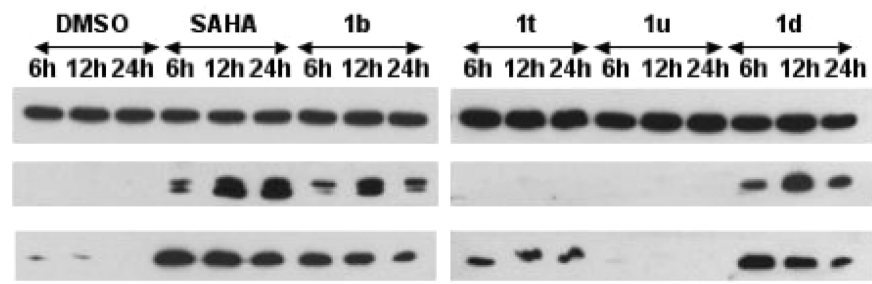

B-tubuline

p21

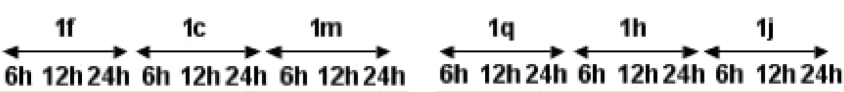
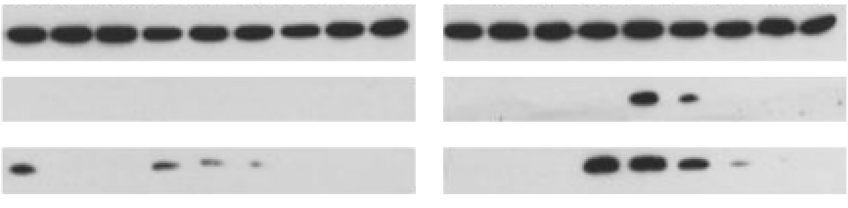

$\beta$-tubuline

p21

Acetylated H4
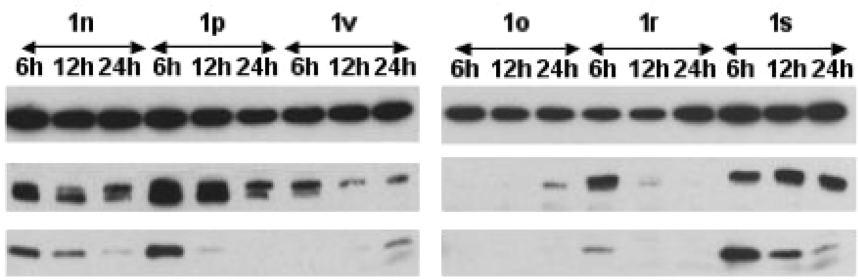

$\beta$-tubuline

p21

Acetylated $\mathrm{H4}$
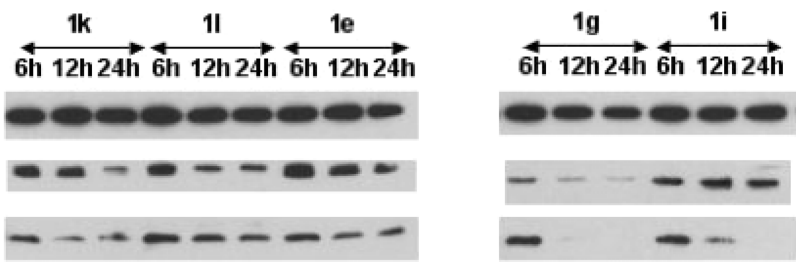

p-tubuline
p21
Acetylated H4

Figure 2. Western blot analysis of acetylated H4 and p21 levels in SKBR3 cells following treatment with the indicated 1a-v analogues. Cells were examined after 6,12 , and $24 \mathrm{~h}$ of incubation with SAHA derivatives $(2 \mu \mathrm{M})$ or solvent (DMSO). $\beta$-Tubulin levels are shown to indicate comparable loading of cell lysates. 


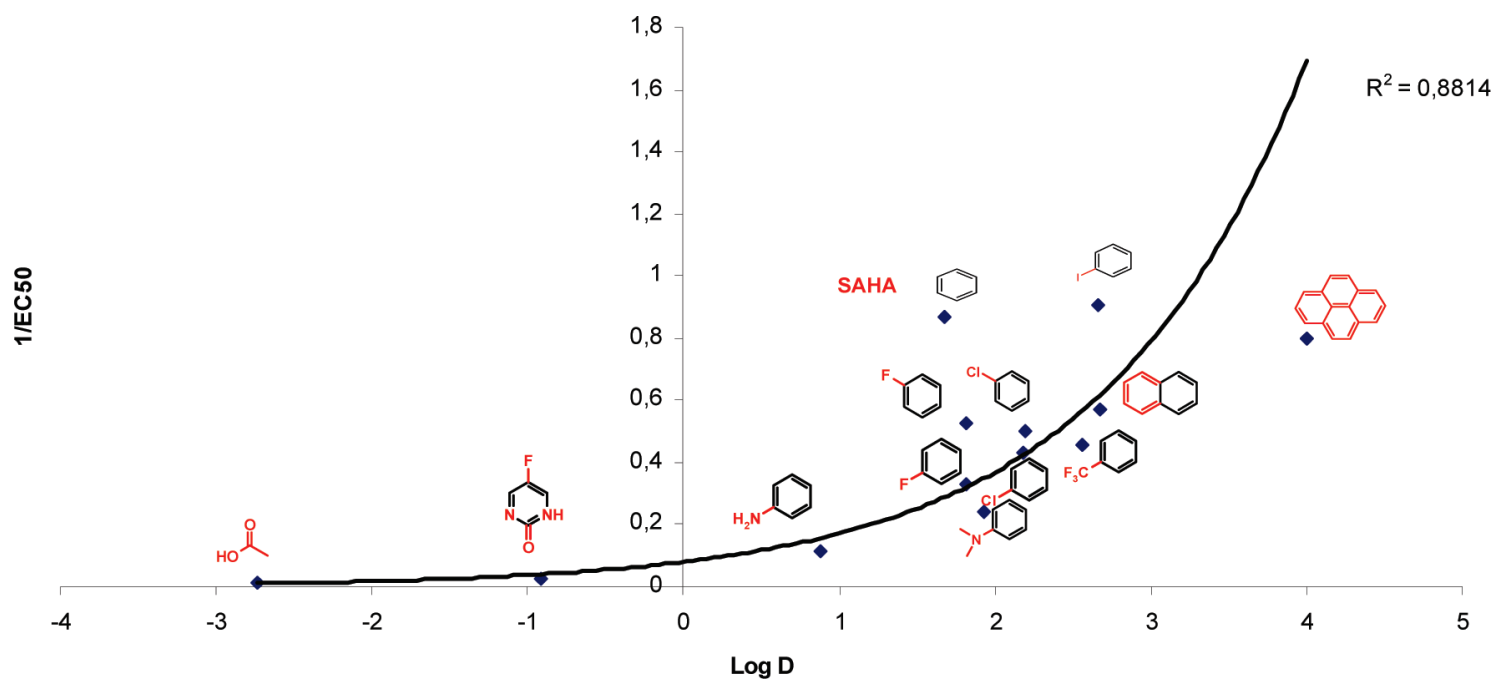

Figure 3. Structure-activity relationships of SAHA derivatives by correlation of their capping group hydrophobicity (log $D$ ) with respect to their observed antiproliferative activity $\left(\mathrm{EC}_{50}\right)$.

have been developed by Marks and Breslow ${ }^{27}$ as well as by Meinke and co-workers from the Merck Research Laboratories. ${ }^{28}$ However, these were too toxic to be considered as potential drug candidates.

In this paper, we report a mild two-step synthesis of a library of new substituted SAHA parent derivatives from commercially cheap available reagents (Scheme 2). This high-yield synthesis varies the nature of the hydrophobic capping group. While the presented chemistry might not be considered particularly new, to the best of our knowledge, the compounds and, more importantly, the influence of the capping group substitution in the antitumoral selectivity of the corresponding SAHA derivatives remain unclear and a few studies ${ }^{29-31}$ have examined the impact of this part of molecule on its biological activities. Unexpectedly, the study reveals selective improvement in the antileukemic activity of some of these SAHA analogues.

\section{Discussion}

The first step consists of a peptide coupling reaction using various aniline derivatives and suberic acid monomethyl ester with an efficient and versatile benzotriazol-1-yloxytris(dimethylamino)phosphonium hexafluorophosphate coupling reagent (BOP). ${ }^{32}$ The obtained ester is successfully transformed into its corresponding hydroxamic derivative by using hydroxylamine $\left(50 \% \mathrm{H}_{2} \mathrm{O}\right)$ in refluxing methanol for $2 \mathrm{~h}$. All of the synthesized products were obtained in goodto-excellent yields, varying from $49 \%$ to $95 \%$ (Table 1).

$\mathbf{1} \mathbf{a}-\mathbf{v}$ were first examined for their antiproliferative and histone deacetylation activities in a cell-based assay. 1d, 1e, $\mathbf{1 g}-\mathbf{i}, \mathbf{1 k}, \mathbf{1 n}, \mathbf{1 p}, \mathbf{1 r}$, and $\mathbf{1 s}$ inhibited SKBR3-breast-derived cell line proliferation, with $\mathrm{EC}_{50}$ values varying from 0.95 to 4 $\mu \mathrm{M}$ (Figure 1, Table 1). In contrast, 1b, 1c, 1q, 1m, 1o, 1f, 1l, 1j, and 1v derivatives displayed the weakest antiproliferative activity, with $\mathrm{EC}_{50}$ values ranging from 8.5 to $73.5 \mu \mathrm{M}$; $1 \mathbf{u}$ and 1q proved inactive for concentrations up to $100 \mu \mathrm{M}$. As expected, the antiproliferative activity of the various compounds correlated well with their time-course ability to upregulate histone $\mathrm{H} 4$ acetylation and p21/WAF1 cell cycle inhibitor accumulation in treated cell extracts (Figure 2).

The nature and presence of a substituent on the aryl moiety of the capping group greatly influence the antiproliferative

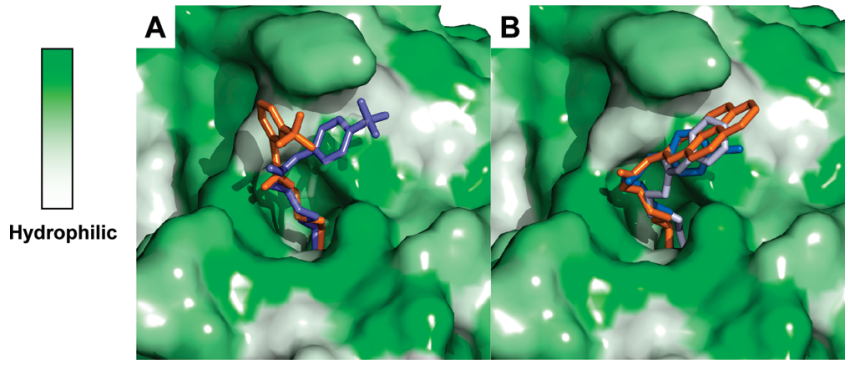

Figure 4. Predicted binding of SAHA derivatives to HDAC8. HDAC8 (PDB code 1T69) is represented as a solid surface and is oriented to illustrate the interaction with SAHA derivatives. The color code corresponds to hydrophilicity. Ligands are shown as sticks. FlexX 2.0 was used to predict the mode of binding of various SAHA derivatives as described in the Experimental Section: (A) 1f (orange) and 1g (blue); (B) 1s (orange), 1k (blue), SAHA (white).

activity of the considered compounds. The presence of a substituent in the ortho position reduced the compound's antiproliferative activity with respect to meta- or para-substituted derivatives. Nevertheless, in these two latter cases, the nature of the substituents greatly influences the activity. In contrast to iodo, naphthyl, or pyrene groups, electron-donating (e.g., $\mathrm{NH}_{2}, \mathrm{NMe}_{2}$, or $\mathrm{OH}$ ) or electron-withdrawing (e.g., $\mathrm{NO}_{2}$ or $\mathrm{CN}$ ) groups did not improve the compound's antiproliferative activity. The results from these latter cases also suggest that the steric hindrance generated and hydrophobic nature of these groups constitute the most important factors to be taken into consideration during the design of most potent SAHA analogues.

Taking into consideration the $\log D$ parameter, which reflects the true behavior and bioavailability of an ionizable compound in a solution at a given $\mathrm{pH}$, a significant correlation with antiproliferative activity was observed (Figure 3 ). Indeed, derivatives displaying the highest $\log D$ values (e.g., the most hydrophobic derivatives $\mathbf{1 k}, \mathbf{1 p}$, and 1s) also displayed higher antiproliferative activity, in agreement with the previously mentioned results.

We thus developed a molecular approach for modeling selected SAHA derivatives based on available structural information regarding human HDAC8 in complex with SAHA (PDB code 1T69). ${ }^{18,33}$ For all the derivatives, the 
A

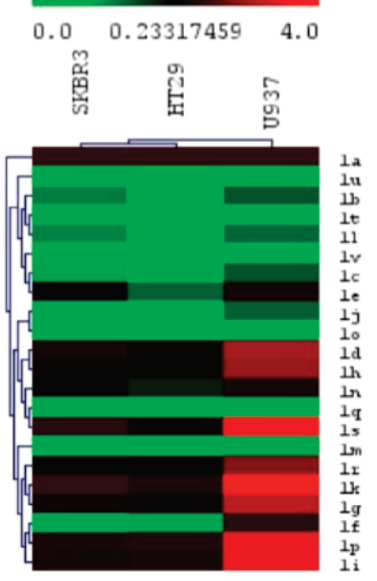

SKBR3

C

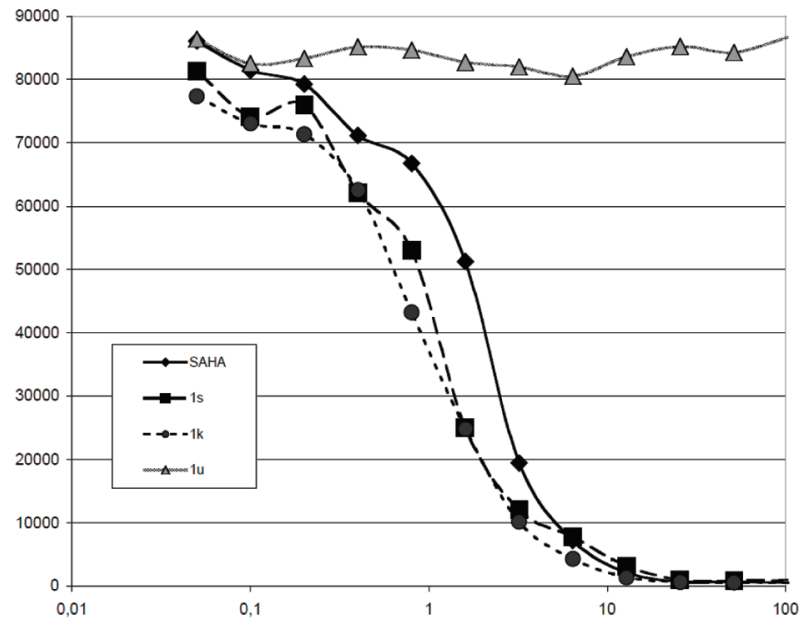

B

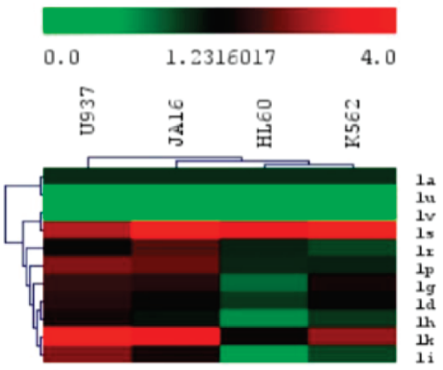

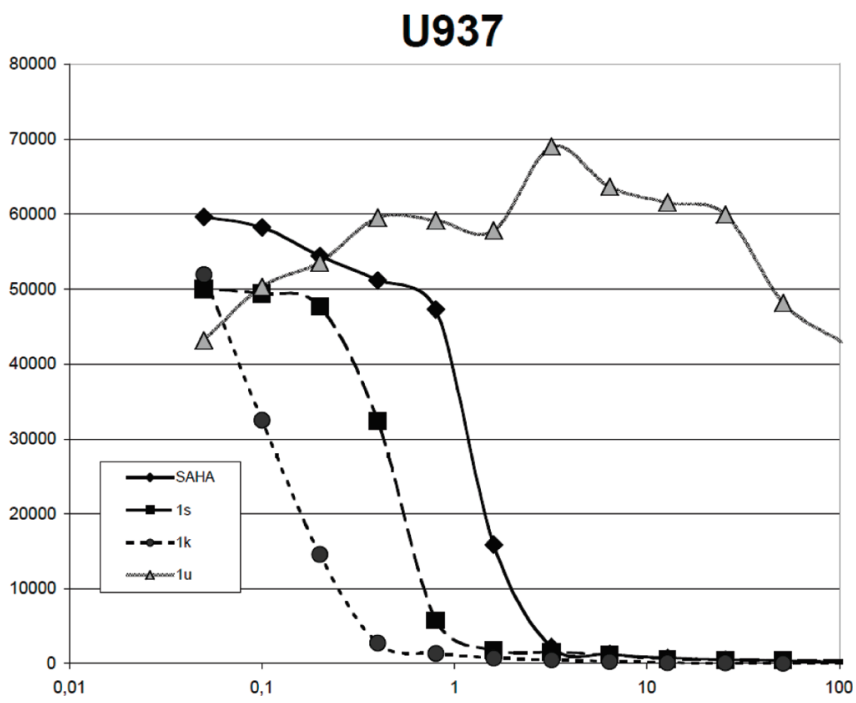

Figure 5. Antiproliferative activity of SAHA derivatives in different cancer-derived cell lines. (A) Screening of SAHA analogues for their antiproliferative activity in breast-derived SKBR3, colon-derived HT29, and leukemia-derived U937 tumor cell lines. The antiproliferative activity profile was reported as the ratio between SAHA analogue and SAHA antiproliferative activities and calculated as the ratio $R=$ $\left[1 / \mathrm{EC}_{50}(\mathrm{x})\right] /\left[1 / \mathrm{EC}_{50}(\mathrm{SAHA})\right]$. These data were translated into a color code using MEV multiexperiment viewer (SAHA analogues with $R>1$ are represented in red, and compounds with $R<1$ are in green; a black color indicates molecules with $R=1$ ). (B) Activity comparison for SAHA analogues in U937, Jurkat JA16, HL60, and K562 leukemias, as described in (A). (C) Dose-response activity of 1s, 1k, and 1u compared to SAHA in U937 cells for the indicated range of concentrations $(0.1-100 \mu \mathrm{M})$. Results are expressed as relative light units (RLUs).

hydroxamate linker moiety adopted a very similar conformation in the binding pocket. In contrast, the orientation of the aromatic group varied, enabling the detection of two populations correlated to biological activities. In all active derivatives, the apolar head was found in the same orientation as SAHA in the X-ray structure; for inactive compounds, however, a different orientation was observed (Figures 4). The result was particularly striking with compounds $\mathbf{1 f}$ and $\mathbf{1 g}$, which correspond to the meta and para isomers of the same compound (Figure 4A). The aromatic moiety of biologically active SAHA derivatives was found to be stabilized by direct interaction with the tyrosine Y306 residue.

The antiproliferative activity of the various SAHA derivatives was further investigated in various tumor-derived cell lines. Surprisingly, compared to SAHA, compounds 1d, 1e, 1g, 1h, 1i, 1k, 1n, 1p, 1r, 1s displayed more efficient antiproliferative activity toward the leukemia cell line U937. When assayed against the SKBR3 and HT29 solid tumor-derived cell lines, however, the antiproliferative activities of the same compounds were comparable to that of SAHA (Figure 5A).
Interestingly, this more efficient antiproliferative activity toward the leukemia cell line U937 was further verified on other leukemia cell lines (Figure 5B).

Hence, the pyrene variant $1 \mathrm{~s}\left(\mathrm{EC}_{50}=0.4 \mu \mathrm{M}\right)$ and the iodosubstituted SAHA derivative $1 \mathbf{k}\left(\mathrm{EC}_{50}=0.12 \mu \mathrm{M}\right)$ proved 3and 10-fold more active than SAHA $\left(\mathrm{EC}_{50}=1.2 \mu \mathrm{M}\right)$, respectively, when assayed against U937 cells. In contrast, both compounds presented antiproliferative activity comparable to that of SAHA $\left(\mathrm{EC}_{50} \approx 1 \mu \mathrm{M}\right)$ when evaluated in SKBR3 cells (Figure 5C). This differential activity of $\mathbf{1 k}$ and 1s correlated well with prolonged $\mathrm{H} 4$ acetylation and higher induction of p21 levels in comparison to SAHA-treated cells in U937 but not SKBR3 cells lines (Figure 6). Together, these results indicate that the increased antiproliferative activity displayed by $\mathbf{1 k}$ and $\mathbf{1 s}$ toward leukemia cell lines does not result from increased broad toxicity. Indeed, when assayed on cultures of peripheral blood mononuclear cells from normal blood donors, $\mathbf{1 k}$ and $\mathbf{1 s}$ displayed cell toxicity comparable to that of SAHA (therapeutic ratios of 15, 30, and 155 for $\mathbf{1 s ,} \mathbf{1 k}$, and SAHA, respectively) (Figure 7). In vivo toxicity was also evaluated by monitoring the body weight, survival, and 
SKBR3
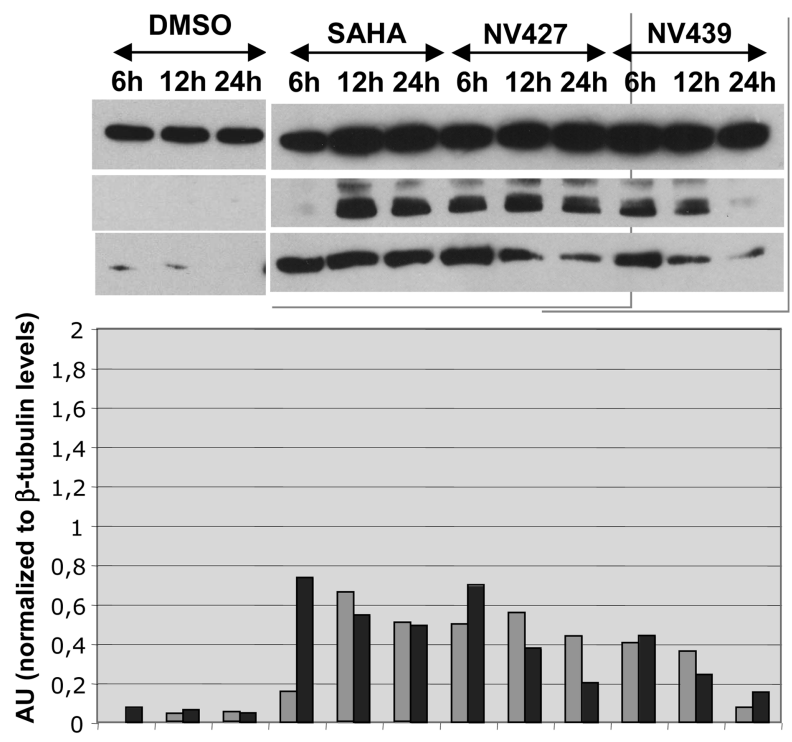

$6 \mathrm{H} \quad 12 \mathrm{H} \quad 24 \mathrm{H} \quad 6 \mathrm{H} \quad 12 \mathrm{H} \quad 24 \mathrm{H} \quad 6 \mathrm{H} \quad 12 \mathrm{H} \quad 24 \mathrm{H} \quad 6 \mathrm{H} \quad 12 \mathrm{H} \quad 24 \mathrm{H}$

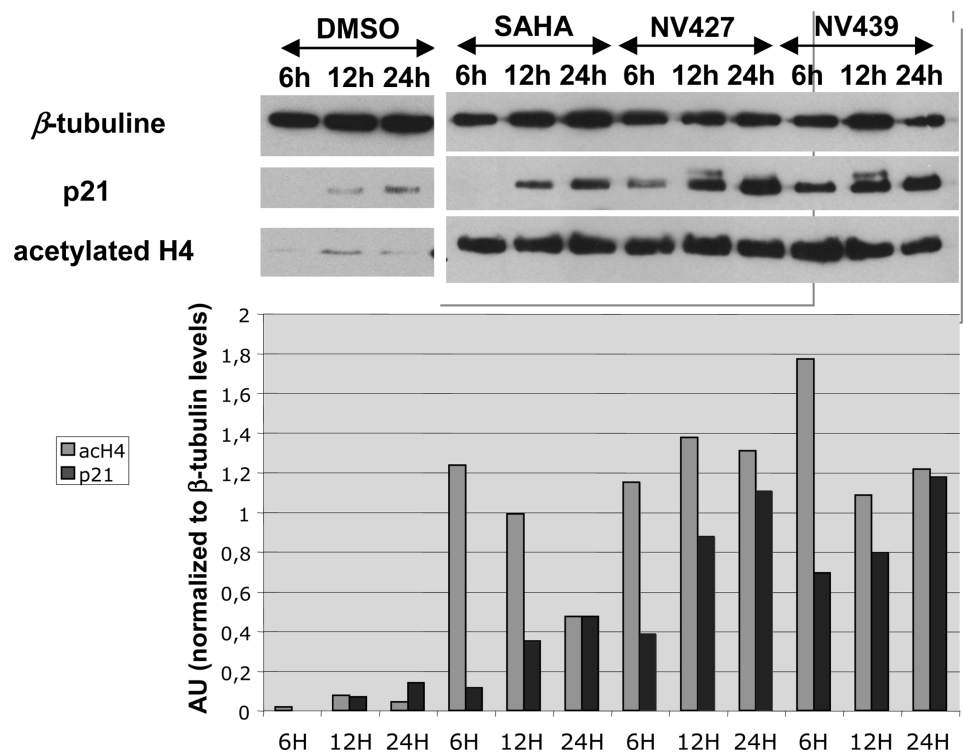

Figure 6. Western blot analysis of acetylated H4 and p21 levels in SKBR3 and U937 cells following treatment with SAHA analogues. Cells were examined after 6,12 , and $24 \mathrm{~h}$ of incubation with SAHA derivatives $(2 \mu \mathrm{M})$ or solvent (DMSO). Bands were quantified using ImageJ, and results are presented after normalization of specific $\mathrm{p} 21$ and acetylated $\mathrm{H} 4$ signals to $\beta$-tubulin levels.
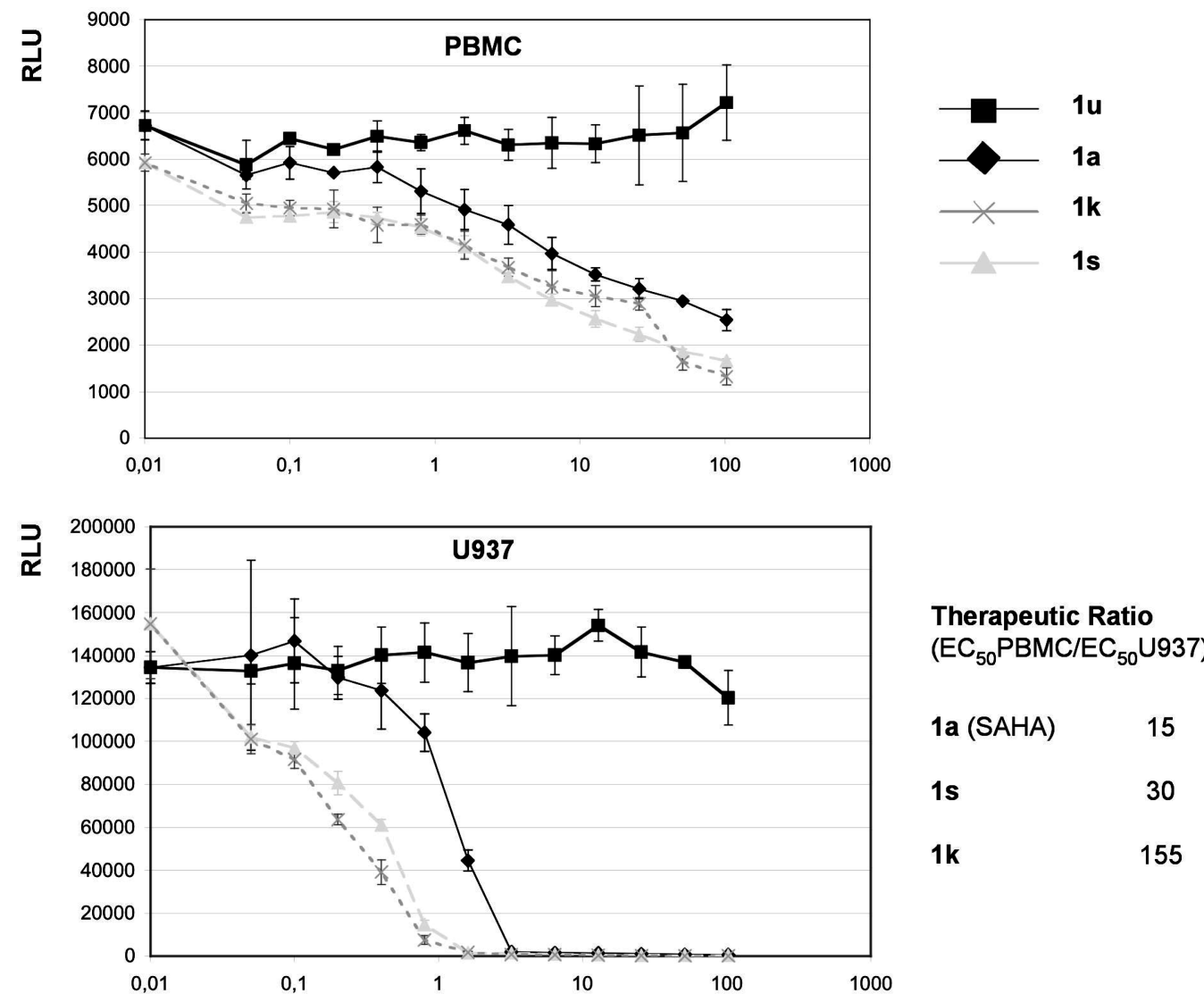

Figure 7. Dose-response activity of $\mathbf{1 k}, \mathbf{1 s}$, and $\mathbf{1 u}$ compared to SAHA in U937 cells and peripheral blood mononuclear cell (PBMC) cultures for the indicated range of concentrations $(0.1-100 \mu \mathrm{M})$. Results are expressed as relative light units (RLUs). EC Ev $_{50}$ values derived from these curves were used to calculate a therapeutic ratio $\left(\mathrm{TR}=\mathrm{EC}_{50}(\mathrm{PBMC}) / \mathrm{EC}_{50}(\mathrm{U} 937)\right)$ and are presented in the table in the lower-right corner.

hematological numeration of blood cells from mice treated orally via forced feeding with $50(\mathrm{mg} / \mathrm{kg}) /$ day of $1 \mathbf{k}$ and SAHA for 2 weeks (Table 2). No deaths were observed among the differentially treated groups during either the treatment period or in the month following interruption of the treatment. Further, mice treated with $\mathbf{1 k}$ displayed indistinguishable 
Table 2. Blood Analysis (Mean \pm SEM)

\begin{tabular}{|c|c|c|c|c|}
\hline sample & & CTL group & 1a group & 1k group \\
\hline \multicolumn{5}{|c|}{ Number of Platelets $\left(10^{3} / \mathrm{mm}^{3}\right)$} \\
\hline $\mathrm{J} 3$ & $n=3$ & $500 \pm 33.5$ & $428.0 \pm 20.2$ & $481.3 \pm 27.4$ \\
\hline J5 & $n=3$ & $454 \pm 93$ & $617.0 \pm 29.7$ & $478.3 \pm 84.0$ \\
\hline $\mathrm{J} 12$ & $n=3$ & $514 \pm 42.8$ & $538.0 \pm 40.8$ & $537 \pm 28.3$ \\
\hline \multicolumn{5}{|c|}{ Mean Platelet Volume $\left(\mu \mathrm{m}^{3}\right)$} \\
\hline $\mathrm{J} 3$ & $n=3$ & $8.2 \pm 0.1$ & $7.9 \pm 0.3$ & $8.2 \pm 0.3$ \\
\hline J5 & $n=3$ & $8.4 \pm 0.5$ & $7.7 \pm 0.2$ & $8.6 \pm 0.6$ \\
\hline $\mathrm{J} 12$ & $n=3$ & $8.8 \pm 0.1$ & $8.4 \pm 0.1$ & $8.7 \pm 0.2$ \\
\hline \multicolumn{5}{|c|}{ Number of Red Blood Cells $\left(10^{6} / \mathrm{mm}^{3}\right)$} \\
\hline $\mathrm{J} 3$ & $n=3$ & $8.6 \pm 0.4$ & $7.9 \pm 0.05$ & $7.9 \pm 0.3$ \\
\hline J5 & $n=3$ & $8.1 \pm 0.2$ & $8.3 \pm 0.1$ & $8.02 \pm 0.4$ \\
\hline $\mathrm{J} 12$ & $n=3$ & $7.7 \pm 0.1$ & $7.6 \pm 0.1$ & $6.9 \pm 0.2$ \\
\hline \multicolumn{5}{|c|}{ Mean Cell Volume of red Cells $\left(\mu \mathrm{m}^{3}\right)$} \\
\hline $\mathrm{J} 3$ & $n=3$ & $44 \pm 0.3$ & $44.4 \pm 0.1$ & $44.0 \pm 0.05$ \\
\hline J5 & $n=3$ & $43.7 \pm 0.4$ & $44.1 \pm 0.2$ & $43.9 \pm 0.4$ \\
\hline $\mathrm{J} 12$ & $n=3$ & $43.9 \pm 0.5$ & $44.5 \pm 0.2$ & $43.7 \pm 0.5$ \\
\hline \multicolumn{5}{|c|}{ Number of White Blood Cells $\left(10^{3} / \mathrm{mm}^{3}\right)$} \\
\hline $\mathrm{J} 3$ & $n=3$ & $7.4 \pm 1.2$ & $8.4 \pm 1.4$ & $8.5 \pm 1.3$ \\
\hline J5 & $n=3$ & $9.1 \pm 1.2$ & $5.9 \pm 0.5$ & $7.5 \pm 0.7$ \\
\hline $\mathrm{J} 12$ & $n=3$ & $8.1 \pm 0.5$ & $8.3 \pm 0.6$ & $7.5 \pm 1.2$ \\
\hline \multicolumn{5}{|c|}{ Hematocrit (\%) } \\
\hline $\mathrm{J} 3$ & $n=3$ & $37.8 \pm 2.2$ & $35.0 \pm 0.2$ & $34.7 \pm 1.5$ \\
\hline $\mathrm{J} 5$ & $n=3$ & $35.3 \pm 1.2$ & $36.5 \pm 0.8$ & $35.2 \pm 2.1$ \\
\hline $\mathrm{J} 12$ & $n=3$ & $34.0 \pm 0.8$ & $33.7 \pm 0.3$ & $30.2 \pm 0.7$ \\
\hline \multicolumn{5}{|c|}{$\%$ of Weight at J3 } \\
\hline $\mathrm{J} 3$ & $n=3$ & $100 \pm 0$ & $100 \pm 0$ & $100 \pm 0$ \\
\hline $\mathrm{J} 5$ & $n=3$ & $96.7 \pm 1.0$ & $94.9 \pm 0.2$ & $99.7 \pm 0.3$ \\
\hline $\mathrm{J} 12$ & $n=3$ & $93.9 \pm 1.7$ & $96.2 \pm 1.4$ & $97.8 \pm 0.8$ \\
\hline
\end{tabular}

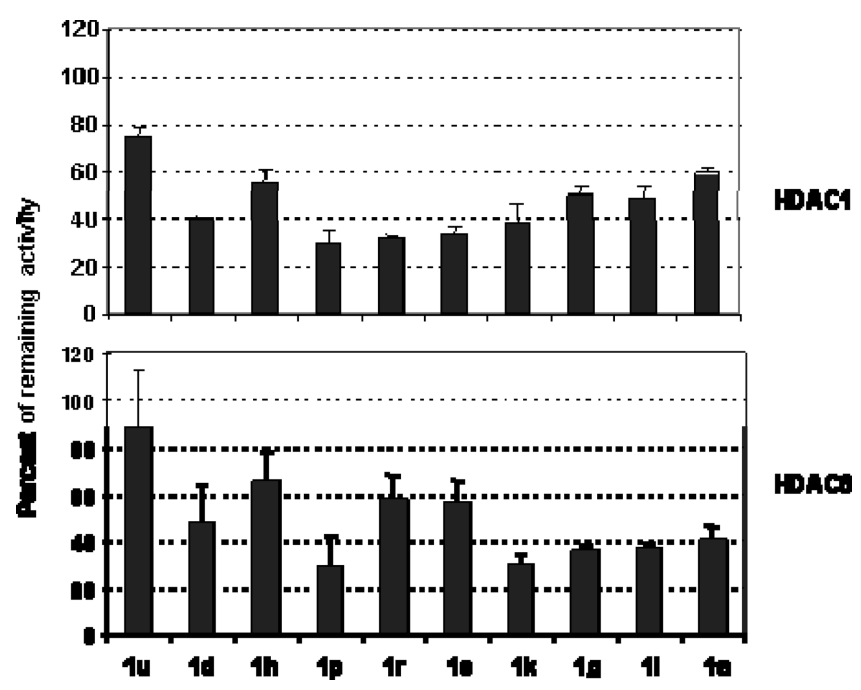

Figure 8. Effect of SAHA analogues $(1 \mu \mathrm{M})$ on cell-derived HDAC1 and HDAC6 deacetylase activity.

body weights and hematological counts compared to both SAHA-treated and control mice.

The reason for the difference in cellular activity among these compounds is unclear, but it may be due to differences in the cellular permeability or, more likely, HDAC expression profile between leukemia cells and solid tumor-derived cell lines. To gain preliminary insight into this possibility, 1d, 1e, $1 \mathbf{g}-\mathbf{i}, \mathbf{1 k}, \mathbf{1 n}, \mathbf{1 p}, \mathbf{1 r}$, and $\mathbf{1 s}$ were compared to SAHA in a deacetylase activity assay using cell-derived HDAC1 (class I
HDAC representative) and HDAC6 (class II HDAC representative), showing comparable inhibition of both HDAC1 and HDAC6 activity (Figure 8).

\section{Conclusion}

Potent SAHA derivatives with low micromolar range antiproliferative and histone hyperacetylation activities were obtained by increasing the size of the hydrophobic region (1s) or by substitution of the phenyl SAHA capping group in the meta or para position (e.g., as in derivative 1k). In this context, compounds displaying up to a 10-fold improvement in antileukemic activity compared to SAHA have been identified. The development of SAHA analogues like $\mathbf{1 k}$ with a peculiar profile of inhibition toward leukemic cells not only raises the question of the implication of distinct HDAC(s) and/or other molecular determinants in this pathology but also may be useful for dissecting their underlying biological functions. These compounds and the related method of synthesis described will thus provide invaluable tools to investigate further the underlying molecular basis of improved cell-specific antiproliferative activity. Such knowledge might prove useful in the future for improving selectivity while reducing the side effects of HDAC inhibitors developed in the clinic, particularly for the treatment of leukemias. These compounds may further represent valuable cancer therapy methods, for example, in association with other proapoptotic drugs.

\section{Experimental Section}

All solvents were purified according to reported procedures, and the reagents used were commercially available. Methanol, ethyl acetate, dichloromethane, and petroleum ether $\left(35-60^{\circ} \mathrm{C}\right)$ were purchased from SDS and used without further purification. Column chromatography was performed on SDS silica gel (70-230 mesh). ${ }^{1} \mathrm{H}$ NMR and ${ }^{13} \mathrm{C}$ NMR spectra were recorded in MeOD or DMSO- $d_{6}$ on a Bruker AC 300 spectrometer working at 300 and $75 \mathrm{MHz}$, respectively (the usual abbreviations are used: s, singlet; d, doublet; t, triplet; q:, quadruplet; m, multiplet). Tetramethylsilane was used as the internal standard. All chemical shifts are given in ppm. Purity (up to 95\%) of all the synthesized compounds has been established by HPLC analysis, and mass spectroscopy analysis was performed by the Spectropole (Analytical Laboratory) of the University Paul Cézanne (Marseille, France).

General Procedure for the Synthesis of SAHA 1a and Its Parent Analogues 1b-v. In a $50 \mathrm{~mL}$ two-necked round flask, aniline $\left(279 \mathrm{mg}, 310^{-3} \mathrm{~mol}\right)$ and methyl ester suberic acid (564 mg, $\left.310^{-3} \mathrm{~mol}\right)$ were placed in anhydrous dichloromethane $(15 \mathrm{~mL})$ at room temperature. The mixture was placed under stirring. Diisopropylamine $\left(1.37 \mathrm{~mL}, 1.06 \times 10^{-2} \mathrm{~mol}\right)$ was added, followed by the addition of the coupling reagent (BOP) $(1.37 \mathrm{~g}$, $3 \times 10^{-3} \mathrm{~mol}$ ) dissolved in $5 \mathrm{~mL}$ of $\mathrm{CH}_{2} \mathrm{Cl}_{2}$. The mixture was stirred for $12 \mathrm{~h}$ at $20^{\circ} \mathrm{C}$. The solvent was removed under vacuum and the crude residue purified by chromatography on a silica gel column using EtOAc/petroleum ether as eluent (1/1 to $1 / 0)$. This procedure afforded the expected coupling product as a white solid at $85 \%$ yield. ${ }^{1} \mathrm{H}$ NMR (DMSO- $\left.d_{6}\right): \delta=7.59-6.69(\mathrm{~m}, 5 \mathrm{H}), 4.83$ $(\mathrm{s}, 1 \mathrm{H}), 3.63(\mathrm{~s}, 3 \mathrm{H}), 2.38-2.27(\mathrm{~m}, 3 \mathrm{H}), 1.70-1.29(\mathrm{~m}, 7 \mathrm{H}) .{ }^{13} \mathrm{C}$ NMR (DMSO- $\left.d_{6}\right): \delta=176.44,175.01,140.33,130.54,130.28$, $125.59,121.70,117.26,52.55,38.41,35.21,30.39,30.33,27.18$, 26.30.

To a stirred solution of the previous derivative in methanol $(15 \mathrm{~mL})$ was added a solution of hydroxylamine ( $50 \%$ in water). The resulting solution was stirred for $3 \mathrm{~h}$ at $60^{\circ} \mathrm{C}$. The solvent was removed under vacuum and the crude residue purified by chromatography on a silica gel column using EtOAc/MeOH 
as eluent (1/1 to $0 / 1)$. This afforded the expected derivative $1 \mathbf{a}$ as a white solid at $92 \%$ yield: $\mathrm{mp}=161{ }^{\circ} \mathrm{C} .{ }^{1} \mathrm{H}$ NMR (DMSO- $\left.d_{6}\right)$ : $\delta=10.37(\mathrm{~s}, 1 \mathrm{H}), 9.86(\mathrm{~s}, 1 \mathrm{H}), 8.70(\mathrm{~s}, 1 \mathrm{H}), 7.66-6.99(\mathrm{~m}, 5 \mathrm{H})$, $2.52-2.50(\mathrm{~m}, 1 \mathrm{H}), 2.31-2.22(\mathrm{~m}, 2 \mathrm{H}), 1.99-1.88(\mathrm{~m}, 2 \mathrm{H})$, $1.58-1.06(\mathrm{~m}, 8 \mathrm{H}) .{ }^{13} \mathrm{C}$ NMR (DMSO- $\left.d_{6}\right): \delta=171.67,169.58$, $139.54,129.00,123.32,119.42,36.71,32.59,28.74,25.38$. $\mathrm{C}_{14} \mathrm{H}_{20} \mathrm{~N}_{2} \mathrm{O}_{3}$. MS $\left(\mathrm{ESI}^{+}\right) \mathrm{m} / z 264.1474\left(100 \%,\left(\mathrm{M}+\mathrm{H}^{+}\right)\right)$.

Compound 1b. Yellow oil crystallizing on standing: $\mathrm{mp}=142^{\circ} \mathrm{C}$. ${ }^{1} \mathrm{H}$ NMR (DMSO- $\left.d_{6}\right): \delta=9.43(\mathrm{~s}, 1 \mathrm{H}), 7.21-7.18(\mathrm{~m}, 2 \mathrm{H})$, 6.50-6.47 (m, 2H), $2.51(\mathrm{~s}, 1 \mathrm{H}), 2.22-1.92(\mathrm{~m}, 4 \mathrm{H}), 1.48-1.26$ $(\mathrm{m}, 10 \mathrm{H}) .{ }^{13} \mathrm{C}$ NMR (DMSO- $\left.d_{6}\right): \delta=171.18,170.08,145.42$, 129.50, 121.80, 114.70, 37.07, 33.14, 30.27, 29.34, 29.30, 26.15, 25.95. $\mathrm{C}_{14} \mathrm{H}_{21} \mathrm{~N}_{3} \mathrm{O}_{3} . \mathrm{MS}\left(\mathrm{ESI}^{+}\right) m / z 279.1583\left(100 \%,\left(\mathrm{M}+\mathrm{H}^{+}\right)\right)$.

Compound 1c. Yellow oil crystallizing on standing: $\mathrm{mp}=$ $122{ }^{\circ} \mathrm{C} .{ }^{1} \mathrm{H}$ NMR (DMSO- $\left.d_{6}\right): \delta=9.43(\mathrm{~s}, 1 \mathrm{H}), 7.21-7.18(\mathrm{~m}$, $2 \mathrm{H}), 6.50-6.47(\mathrm{~m}, 2 \mathrm{H}), 2.51(\mathrm{~s}, 1 \mathrm{H}), 2.22-1.92(\mathrm{~m}, 4 \mathrm{H}), 1.48-$ $1.26(\mathrm{~m}, 10 \mathrm{H}) .{ }^{13} \mathrm{C} \mathrm{NMR}\left(\mathrm{DMSO}-d_{6}\right): \delta=175.03,172.87,155.43$, 131.03, 119.06, 116.37, 37.48, 32.12, 24.82, 24.75, 23.61. $\mathrm{C}_{14} \mathrm{H}_{20^{-}}$ $\mathrm{N}_{2} \mathrm{O}_{4} \cdot \mathrm{MS}\left(\mathrm{ESI}^{+}\right) m / z 280.1423\left(100 \%,\left(\mathrm{M}+\mathrm{H}^{+}\right)\right)$.

Compound 1d. Yellow oil crystallizing on standing: $\mathrm{mp}=$ $154{ }^{\circ} \mathrm{C} .{ }^{1} \mathrm{H}$ NMR $\left(\mathrm{DMSO}-d_{6}\right): \delta=10.37(\mathrm{~s}, 1 \mathrm{H}), 10.08(\mathrm{~s}, 1 \mathrm{H})$, $7.63-6.90(\mathrm{~m}, 4 \mathrm{H}), 2.52-2.23(\mathrm{~m}, 3 \mathrm{H}), 2.02-1.86(\mathrm{~m}, 2 \mathrm{H})$, $1.59-1.26(\mathrm{~m}, 8 \mathrm{H}) .{ }^{13} \mathrm{C} \mathrm{NMR}$ (DMSO- $\left.d_{6}\right): \delta=172.04,169.58$, $162.45,141.40,130.51,115.04,1109.63,106.12,36.73,32.58$, 28.71, 25.37, 25.24. $\mathrm{C}_{14} \mathrm{H}_{19} \mathrm{FN}_{2} \mathrm{O}_{3}$. MS $\left(\mathrm{ESI}^{+}\right) \mathrm{m} / z 282.1383$ $\left(100 \%,\left(\mathrm{M}+\mathrm{H}^{+}\right)\right)$

Compound 1e. Pale viscous yellow oil: ${ }^{1} \mathrm{H}$ NMR (DMSO- $d_{6}$ ): $\delta=9.95(\mathrm{~s}, 1 \mathrm{H}), 7.61-7.08(\mathrm{~m}, 4 \mathrm{H}), 2.51-1.26(\mathrm{~m}, 14 \mathrm{H}),{ }^{13} \mathrm{C}$ NMR (DMSO- $\left.d_{6}\right): \delta=173.86,171.67,135.96,121.28,121.15$, 115.66, 115.36, 36.53, 33.55, 28.69, 28.51, 25.34, 24.62. $\mathrm{C}_{14} \mathrm{H}_{19} \mathrm{FN}_{2} \mathrm{O}_{3} . \mathrm{MS}\left(\mathrm{ESI}^{+}\right) m / z 282.1383\left(100 \%,\left(\mathrm{M}+\mathrm{H}^{+}\right)\right)$.

Compound 1f. Yellow oil crystallizing on standing: $\mathrm{mp}=52$ ${ }^{\circ} \mathrm{C} .{ }^{1} \mathrm{H}$ NMR (DMSO- $\left.d_{6}\right): \delta=9.60(\mathrm{~s}, 1 \mathrm{H}), 7.38-7.34(\mathrm{~m}, 2 \mathrm{H})$, 6.99-6.44 (m, 4H), 2.52-2.50 (m, 1H), 2.25-1.93 (m, 4H), $1.58-1.22(\mathrm{~m}, 7 \mathrm{H}) .{ }^{13} \mathrm{C}$ NMR (DMSO- $\left.d_{6}\right): \delta=170.97,169.60$, $153.47,148.62,140.92,131.31,121.28,115.90,115.34,36.55$, 32.59, 28.73, 25.39. $\mathrm{C}_{15} \mathrm{H}_{19} \mathrm{~F}_{3} \mathrm{~N}_{2} \mathrm{O}_{3}$. MS $\left(\mathrm{ESI}^{+}\right) \mathrm{m} / z 332.1348$ $\left(100 \%,\left(\mathrm{M}+\mathrm{H}^{+}\right)\right)$

Compound 1g. Yellow oil crystallizing on standing: $\mathrm{mp}=64$ ${ }^{\circ} \mathrm{C} .{ }^{1} \mathrm{H}$ NMR (DMSO- $\left.d_{6}\right): \delta=10.26(\mathrm{~s}, 1 \mathrm{H}), 7.79-7.62(\mathrm{~m}, 4 \mathrm{H})$, $2.51-1.26(\mathrm{~m}, 14 \mathrm{H}) .{ }^{13} \mathrm{C}$ NMR (DMSO- $\left.d_{6}\right): \delta=172.36,169.59$, $143.17,126.27,119.22,36.74,32.57,28.69,25.35,24.62$. $\mathrm{C}_{15} \mathrm{H}_{19} \mathrm{~F}_{3} \mathrm{~N}_{2} \mathrm{O}_{3}$. MS $\left(\mathrm{ESI}^{+}\right) \mathrm{m} / z 332.1348\left(100 \%,\left(\mathrm{M}+\mathrm{H}^{+}\right)\right)$.

Compound 1h. White solid: $\mathrm{mp}=146^{\circ} \mathrm{C} .{ }^{1} \mathrm{H}$ NMR (DMSO$\left.d_{6}\right): \delta=10.01(\mathrm{~s}, 1 \mathrm{H}), 7.64-7.32(\mathrm{~m}, 4 \mathrm{H}), 2.51-1.27(\mathrm{~m}, 14 \mathrm{H})$. ${ }^{13} \mathrm{C}$ NMR (DMSO- $\left.d_{6}\right): \delta=171.75,169.46,138.64,128.89$, $126.78,120.89,36.70,32.59,28.74,25.38,25.29,24.79$. $\mathrm{C}_{14} \mathrm{H}_{19} \mathrm{ClN}_{2} \mathrm{O}_{3}$. MS $\left(\mathrm{ESI}^{+}\right) \mathrm{m} / z 298.1084\left(100 \%,\left(\mathrm{M}+\mathrm{H}^{+}\right)\right)$.

Compound 1i. Yellow solid: $\mathrm{mp}=140{ }^{\circ} \mathrm{C}$. ${ }^{1} \mathrm{H}$ NMR (DMSO$\left.d_{6}\right): \delta=10.08(\mathrm{~s}, 1 \mathrm{H}), 7.80(\mathrm{~s}, 1 \mathrm{H}), 7.40-7.26(\mathrm{~m}, 2 \mathrm{H}), 7.07-$ $7.03(\mathrm{~m}, 1 \mathrm{H}), 2.31-2.26(\mathrm{~m}, 2 \mathrm{H}), 1.98-1.93(\mathrm{~m}, 2 \mathrm{H}), 1.57-$ $1.22(\mathrm{~m}, 10 \mathrm{H}) .{ }^{13} \mathrm{C}$ NMR (DMSO- $\left.d_{6}\right): \delta=172.24,169.77$, $140.97,133.37,130.66,123.05,118.91,117.79,36.67,32.56$, 28.64, 25.33. $\mathrm{C}_{14} \mathrm{H}_{19} \mathrm{ClN}_{2} \mathrm{O}_{3}$. MS (ESI $\left.{ }^{+}\right) m / z 298.1084(100 \%$, $\left.\left(\mathrm{M}+\mathrm{H}^{+}\right)\right)$.

Compound 1j. Brown solid: $\mathrm{mp}=68{ }^{\circ} \mathrm{C}$. ${ }^{1} \mathrm{H}$ NMR (DMSO$\left.d_{6}\right): \delta=9.41(\mathrm{~s}, 1 \mathrm{H}), 7.67-7.11(\mathrm{~m}, 4 \mathrm{H}), 2.56-1.27(\mathrm{~m}, 14 \mathrm{H}) .{ }^{13} \mathrm{C}$ NMR (DMSO- $\left.d_{6}\right): \delta=171.81,169.49,136.76,132.94,128.27$, 127.31, 118.57, 35.99, 32.62, 28.73, 25.45. $\mathrm{C}_{14} \mathrm{H}_{19} \mathrm{BrN}_{2} \mathrm{O}_{3}$. MS $\left(\mathrm{ESI}^{+}\right) m / z 342.0579\left(100 \%,\left(\mathrm{M}+\mathrm{H}^{+}\right)\right)$.

Compound 1k. White solid: $\mathrm{mp}=150{ }^{\circ} \mathrm{C} .{ }^{1} \mathrm{H}$ NMR (DMSO$\left.d_{6}\right): \delta=9.99(\mathrm{~s}, 1 \mathrm{H}), 7.62-7.41(\mathrm{~m}, 4 \mathrm{H}), 2.52-2.51(\mathrm{~m}, 2 \mathrm{H})$, $2.30-2.25(\mathrm{~m}, 2 \mathrm{H}), 1.96-1.92(\mathrm{~m}, 2 \mathrm{H}), 1.58-1.25(\mathrm{~m}, 8 \mathrm{H}) .{ }^{13} \mathrm{C}$ NMR (DMSO- $\left.d_{6}\right): \delta=171.92,169.61,139.43,137.64,121.66$, $86.62,36.73,32.57,28.69,25.35,26.26 . \mathrm{C}_{14} \mathrm{H}_{19} \mathrm{IN}_{2} \mathrm{O}_{3} . \mathrm{MS}$ $\left(\mathrm{ESI}^{+}\right) \mathrm{m} / z 390.0440\left(100 \%,\left(\mathrm{M}+\mathrm{H}^{+}\right)\right)$

Compound 11. Pale-yellow oil: ${ }^{1} \mathrm{H}$ NMR (DMSO- $\left.d_{6}\right): \delta=$ $9.780(\mathrm{~s}, 1 \mathrm{H}), 7.38-6.94(\mathrm{~m}, 4 \mathrm{H}), 2.52-2.50(\mathrm{~m}, 1 \mathrm{H}), 2.25-1.22$ $(\mathrm{m}, 13 \mathrm{H}) .{ }^{13} \mathrm{C}$ NMR (DMSO- $\left.d_{6}\right): \delta=180.28,170.60,152.71$, $150.46,127.36,126.85,121.50,119.64,114.27,37.34,33.20$,
29.30, 25.97. $\mathrm{C}_{15} \mathrm{H}_{19} \mathrm{~N}_{3} \mathrm{O}_{3}$. MS (ESI $\left.{ }^{+}\right) \mathrm{m} / z 289.1426(100 \%$, $\left.\left(\mathrm{M}+\mathrm{H}^{+}\right)\right)$.

Compound 1m. Yellow oil crystallizing on standing: $\mathrm{mp}=$ $172{ }^{\circ} \mathrm{C} .{ }^{1} \mathrm{H}$ NMR (DMSO- $\left.d_{6}\right): \delta=9.19$ (s, 1H), 7.43-7.31 $(\mathrm{m}, 9 \mathrm{H}), 2.29-1.18(\mathrm{~m}, 14 \mathrm{H}) .{ }^{13} \mathrm{C}$ NMR (DMSO- $\left.d_{6}\right): \delta=$ $174.98,171.91,145.28,140.04,139.40,135.26,130.36,129.10$, $128.61,127.11,126.12,117.12,115.60,32.60,28.69,25.40$. $\mathrm{C}_{20} \mathrm{H}_{24} \mathrm{~N}_{2} \mathrm{O}_{3}$. MS $\left(\mathrm{ESI}^{+}\right) \mathrm{m} / z 340.1787\left(100 \%,\left(\mathrm{M}+\mathrm{H}^{+}\right)\right)$.

Compound 1n. Brown solid: $\mathrm{mp}=128^{\circ} \mathrm{C}$. ${ }^{1} \mathrm{H}$ NMR (DMSO$\left.d_{6}\right): \delta=9.52(\mathrm{~s}, 1 \mathrm{H}), 7.37-7.34(\mathrm{~d}, J=12 \mathrm{~Hz}, 2 \mathrm{H}), 6.66-6.63$ $(\mathrm{d}, J=8 \mathrm{~Hz}, 2 \mathrm{H}), 2.80(\mathrm{~s}, 6 \mathrm{H}), 2.52-1.23(\mathrm{~m}, 14 \mathrm{H}) .{ }^{13} \mathrm{C} \mathrm{NMR}$ $\left(\right.$ DMSO- $\left.d_{6}\right): \delta=171.12,169.80,147.37,125.37,121.10,112.99$, $36.52,32.57,28.65,25.50,25.34 . \mathrm{C}_{16} \mathrm{H}_{25} \mathrm{~N}_{3} \mathrm{O}_{3}$. MS $\left(\mathrm{ESI}^{+}\right) \mathrm{m} / z$ $307.1896\left(100 \%,\left(\mathrm{M}+\mathrm{H}^{+}\right)\right)$.

Compound 1o. White solid: $\mathrm{mp}=110^{\circ} \mathrm{C} .{ }^{1} \mathrm{H}$ NMR (DMSO$\left.d_{6}\right): \delta=7.96-7.93(\mathrm{~d}, J=12 \mathrm{~Hz}, 2 \mathrm{H}), 6.71-6.59(\mathrm{~m}, 2 \mathrm{H})$, $2.51-1.10(\mathrm{~m}, 12 \mathrm{H}) .{ }^{13} \mathrm{C}$ NMR (DMSO- $\left.d_{6}\right): \delta=176.58,169.58$, 156.05, 136.98, 126.74, 112.74, 34.91, 32.57, 28.70, 25.37, 25.17. $\mathrm{C}_{14} \mathrm{H}_{19} \mathrm{~N}_{3} \mathrm{O}_{5}$. MS $\left(\mathrm{ESI}^{+}\right) m / z 309.3215\left(100 \%,\left(\mathrm{M}+\mathrm{H}^{+}\right)\right)$.

Compound 1p. White solid: $\mathrm{mp}=124{ }^{\circ} \mathrm{C} .{ }^{1} \mathrm{H}$ NMR (DMSO$\left.d_{6}\right): \delta=10.12(\mathrm{~s}, 1 \mathrm{H}), 8.31(\mathrm{~s}, 1 \mathrm{H}), 7.85-7.35(\mathrm{~m}, 7 \mathrm{H}), 2.52-1.22$ $(\mathrm{m}, 13 \mathrm{H}) .{ }^{13} \mathrm{C}$ NMR (DMSO- $\left.d_{6}\right): \delta=172.00,169.61,137,25$, $133.81,129.98,128.61,127.77,127.57,126.71,124.79,120.35$, 115.38, 36.79, 32.61, 28.76, 25.40. $\mathrm{C}_{18} \mathrm{H}_{22} \mathrm{~N}_{2} \mathrm{O}_{3}$. MS (ESI $\left.{ }^{+}\right) \mathrm{m} / z$ $314.1630\left(100 \%,\left(\mathrm{M}+\mathrm{H}^{+}\right)\right)$.

Compound 1q. Pale viscous yellow oil. ${ }^{1} \mathrm{H}$ NMR (DMSO- $\left.d_{6}\right)$ : $\delta=7.74-7.27(\mathrm{~m}, 7 \mathrm{H}), 2.28-1.31(\mathrm{~m}, 14 \mathrm{H}) .{ }^{13} \mathrm{C}$ NMR (DMSO$\left.d_{6}\right): \delta=179.80,172.54,143.65,137.14,128.18,127.30,124.82$, 118.07, 111.67, 35.97, 32.95, 29.29, 29.09. $\mathrm{C}_{17} \mathrm{H}_{21} \mathrm{~N}_{3} \mathrm{O}_{3} . \mathrm{MS}$ $\left(\mathrm{ESI}^{+}\right) \mathrm{m} / z 315.1583\left(100 \%,\left(\mathrm{M}+\mathrm{H}^{+}\right)\right)$.

Compound 1r. Yellow oil crystallizing on standing: $m p=132$ ${ }^{\circ} \mathrm{C} .{ }^{1} \mathrm{H}$ NMR (DMSO- $\left.d_{6}\right): \delta=9.97(\mathrm{~s}, 1 \mathrm{H}), 7.95-7.25(\mathrm{~m}, 9 \mathrm{H})$, $3.89(\mathrm{~s}, 2 \mathrm{H}), 2.52-1.29(\mathrm{~m}, 12 \mathrm{H}) .{ }^{13} \mathrm{C}$ NMR (DMSO-d $\left.d_{6}\right): \delta=$ 171.66, 168.58, 144.06, 143.11, 141.38, 138.73, 136.46, 127.07, $126.38,125.35,120.38,119.72,118.25,116.28,36.84,32.60$, 28.76, 25.45, 25.40. $\mathrm{C}_{21} \mathrm{H}_{24} \mathrm{~N}_{2} \mathrm{O}_{3}$. MS (ESI $\left.{ }^{+}\right) \mathrm{m} / z 352.1787$ $\left(100 \%,\left(\mathrm{M}+\mathrm{H}^{+}\right)\right)$

Compound 1s. Gray solid: $\mathrm{mp}=158{ }^{\circ} \mathrm{C} .{ }^{1} \mathrm{H}$ NMR (DMSO$\left.d_{6}\right): \delta=10.31(\mathrm{~s}, 1 \mathrm{H}), 8.33-7.38(\mathrm{~m}, 10 \mathrm{H}), 6.35(\mathrm{~s}, 1 \mathrm{H}), 2.62-1.40$ $(\mathrm{m}, 12 \mathrm{H}) .{ }^{13} \mathrm{C}$ NMR (DMSO- $\left.d_{6}\right): \delta=170.23,167.29,142.44$, $130.10,130.06,129.75,128.90,128.56,126.19,125.77,125.29$, $124.41,123.93,122.92,120.98,120.43,119.82,112.78,111.19$, $34.03,30.38,26.62,26.54,23.37,23.19 . \mathrm{C}_{24} \mathrm{H}_{24} \mathrm{~N}_{2} \mathrm{O}_{3} . \mathrm{MS}\left(\mathrm{ESI}^{+}\right)$ $m / z 388.1787\left(100 \%,\left(\mathrm{M}+\mathrm{H}^{+}\right)\right)$.

Compound 1t. White solid: $\mathrm{mp}=164{ }^{\circ} \mathrm{C} .{ }^{1} \mathrm{H}$ NMR (DMSO$\left.d_{6}\right): \delta=2.51(\mathrm{~s}, 1 \mathrm{H}), 1.96-1.91(\mathrm{~m}, 5 \mathrm{H}), 1.47-1.19(\mathrm{~m}, 11 \mathrm{H}) .{ }^{13} \mathrm{C}$ NMR (DMSO- $\left.d_{6}\right): \delta=169.78,32.54,28.54,25.32 . \mathrm{C}_{8} \mathrm{H}_{16^{-}}$ $\mathrm{N}_{2} \mathrm{O}_{4}$. MS $\left(\mathrm{ESI}^{+}\right) m / z 204.1110\left(100 \%,\left(\mathrm{M}+\mathrm{H}^{+}\right)\right)$.

Compound 1u. White solid: $\mathrm{mp}=126^{\circ} \mathrm{C}$. ${ }^{1} \mathrm{H}$ NMR (DMSO$\left.d_{6}\right): \delta=3.16(\mathrm{~s}, 2 \mathrm{H}), 2.03-1.92(\mathrm{~m}, 4 \mathrm{H}), 1.43-1.27(\mathrm{~m}, 9 \mathrm{H}) .{ }^{13} \mathrm{C}$ NMR (DMSO- $\left.d_{6}\right): \delta=180.63,170.40,48.90,37.01,32.50$, 29.16, 28.91, 28.59, 25.88, 25.32. $\mathrm{C}_{8} \mathrm{H}_{15} \mathrm{NO}_{4} . \mathrm{MS}\left(\mathrm{ESI}^{+}\right) \mathrm{m} / z$ $189.1001\left(100 \%,\left(\mathrm{M}+\mathrm{H}^{+}\right)\right)$.

Compound 1v. Yellow oil crystallizing on standing: $\mathrm{mp}=$ $62{ }^{\circ} \mathrm{C} .{ }^{1} \mathrm{H}$ NMR (DMSO- $\left.d_{6}\right): \delta=7.71-7.14(\mathrm{~m}, 4 \mathrm{H}), 2.62-1.20$ $(\mathrm{m}, 12 \mathrm{H}) .{ }^{13} \mathrm{C}$ NMR (DMSO- $\left.d_{6}\right): \delta=176.91,167.79,141.38$, 125.57, 121.43, 121.26, 116.53, 109.73, 47.05, 30.65, 26.69, 23.44. $\mathrm{C}_{12} \mathrm{H}_{17} \mathrm{FN}_{4} \mathrm{O}_{4} . \mathrm{MS}\left(\mathrm{ESI}^{+}\right) \mathrm{m} / z \quad 300.2932\left(100 \%,\left(\mathrm{M}+\mathrm{H}^{+}\right)\right)$.

Cell Culture Conditions and Proliferation Assay. The human breast cancer cell line SKBR3 and colon adenocarcinoma cell line HT29 were cultured in Dulbecco's modified Eagle's medium (DMEM) supplemented with 10\% fetal bovine serum (FBS) and $0.1 \%$ sodium pyruvate. The human U937 and HL60 myeloid leukemia cell lines, K562 chronic erythromyeloid leukemia cells, and clone Jurkat leukemia JA16 cells were maintained in RPMI-1640 medium supplemented with $10 \%$ FBS at $37{ }^{\circ} \mathrm{C}$ with $5 \% \mathrm{CO}_{2}$. Peripheral blood mononuclear cells (PBMCs) were obtained from donors whole blood cells and cultured in RPMI- 1640 medium supplemented with $10 \%$ FBS at $37^{\circ} \mathrm{C}$ with $5 \% \mathrm{CO}_{2}$. 
Stock solutions of synthesized and commercial (Merck and Co., Inc.) suberoyl anilide hydroxamic acid (SAHA) as well as the synthesized SAHA derivatives $(10 \mathrm{mM})$ dissolved in dimethyl sulfoxide (DMSO) were aliquotted and stored at $-20{ }^{\circ} \mathrm{C}$

In antiproliferative assays, compounds were assayed for their growth-inhibiting activity toward the described cancer cell lines or PBMCs using the CellTiter-Glo luminescent cell viability assay as described by the manufacturer (Promega Corp.). Briefly, for adherent cells, $10^{4}$ cells were plated onto 96-well plates (white with clear bottom (3610, Corning Costar)) in $100 \mu \mathrm{L}$ of media per well and were allowed to grow overnight before the assay. For cells growing in suspension, $10^{4}$ cells were plated onto 96-well plates immediately before the assay. Compounds were added at different concentrations (varying from 100 to $0.1 \mu \mathrm{M}$ ) to each well, and cell cultures were incubated for $48 \mathrm{~h}$. Vehicle (DMSO) was used as a control, and all compounds were tested in a constant percentage of DMSO (1\%). After addition of $50 \mu \mathrm{L}$ of CellTiter GLO, luminescence was measured using a Centro luminometer (Berthold). $\mathrm{EC}_{50}$ values were determined as the dose of compound required to reduce luminescent values to $50 \%$ of the signal obtained for untreated cell cultures.

SDS-PAGE and Western Blot Analysis. SKBR3 and U937 cells $\left(0.5 \times 10^{6}\right)$ were plated onto six-well cell culture dishes (Corning Costar) and cultured for 6, 12, and $24 \mathrm{~h}$ in $2 \mathrm{~mL}$ of media with the tested compounds ( $2 \mu \mathrm{M}$ final concentration). At each time point, proteins were prepared from the total cell lysates obtained using $50 \mu \mathrm{L}$ of SDS-PAGE sample buffer (80 mM Tris- $\mathrm{HCl}(\mathrm{pH}$ 6.8, 2\% SDS, $100 \mathrm{mM}$ DTT, $10 \%$ glycerol, $0.1 \%$ bromophenol blue). Proteins were resolved by SDS-PAGE (15\% acrylamide) and transferred to nitrocellulose membranes. After blocking with $5 \%$ BSA in TBS with $0.05 \%$ Tween (TBST buffer) for $1 \mathrm{~h}$ at room temperature, membranes were probed overnight at $4{ }^{\circ} \mathrm{C}$ with antiacetylated $\mathrm{H} 4$ (Upstate) and anti-p21/WAF1 (Abcam) antibodies and for $1 \mathrm{~h}$ with an antitubulin $\beta$ antibody (Sigma). Following incubation with the primary antibody, blots were washed three times for $10 \mathrm{~min}$ in TBST buffer, followed by incubation for $1 \mathrm{~h}$ at room temperature with secondary horseradish peroxidase-conjugated antimouse or antirabbit antibodies. After washing, luminescence was developed using WestPico reagent, as recommended by the manufacturer (Pierce). Films were scanned, and densitometric analysis was performed using Image J.

In Vivo Toxicity. The compounds were dissolved in a $50 \%$ Cremophor EL (Sigma) $/ 50 \%$ ethanol mixture followed by heating (up to $60{ }^{\circ} \mathrm{C}$ ) and sonication for $30 \mathrm{~min}$. Once the compound was in solution, water was added to generate the working solution.

Fvb mice were purchased from CERJ (Centre d'Elevage Roger Janvier, France). Mice were maintained under specific pathogen-free conditions in individual ventilated cages with acidified water. All animal procedures were performed in accordance with protocols approved by the local Committee for Animal Experimentation. The 8-week-old mice were randomly assigned to receive either compound $\mathbf{1 a}$ or $\mathbf{1 k}(n=3$ mice per group) at $50 \mathrm{mg} / \mathrm{kg}$ of body weight or vehicle (solvent-only control, $n=3$ mice per group) by oral gavage five times per week for 2 weeks. Differential blood counts were assessed by retroorbital nonlethal eyebleeds before study initiation (J-5), during the study (J5), and at study end points (J12). Heparinized blood samples were immediately processed on a Medonic CA620 analyzer (Boule Medical AB) to determine a full blood picture profile (white cell count, hematocrit, red cell count, and platelet count).

Definition of the Active Site and Docking Parameters for FlexX. A structure-based drug design (SBDD) approach was applied on the $2.91 \AA$ resolution crystallographic structure of human HDAC8 in complex with SAHA (Somoza et al. structure $^{18}$ (PDB code 1T69). We tested the five scoring functions of the Cscore Sybyl module ${ }^{34}$ for docking experiments with FlexX $2.0:^{35}$ FlexXscore, Gscore, Dscore, PMFscore, and Chemscore (http://www.biosolveit.de). We also rescored each docking with our in-house scoring function, GFscore (http://gfscore.cnrsmrs.fr). ${ }^{36}$

The Tripos Sybyl "Structure Preparation Tool" was used to optimize the protein structure before use by FlexX 2.0. Hydrogen atoms were added, bumps and side chain amides corrected, and missing residues added and minimized. The newly obtained PDB file was then injected as such into FlexX 2.0.

For each docking, the "active site" used for docking always comprises a pocket containing all atoms of human HDAC8 no farther than $8 \AA$ from the SAHA crystalline position with a coresubpocket of $3 \AA$ around the SAHA residue. The best parameters were evaluated for each scoring function according to their ability to mimic the crystallographic pose of the SAHA ligand (we formerly corrected the SAHA structure and atom valences according to the NCBI Pubchem structural data server (http://pubchem.ncbi.nlm.nih.gov/)).

Docking with FlexX 2.0. FlexX 2.0 is an incremental construction-docking algorithm involving three steps. FlexX cuts ligand into fragments, places the best one into the binding site, and then makes an incremental construction of the whole ligand. Conformational flexibility of the ligand is taken into account by considering both torsion angle flexibility and conformational flexibility of ring systems. ${ }^{37}$ FlexX by itself does not recognize receptor flexibility; rather, it sees proteins as rigid elements (bodies). Default FlexX parameters were used as supplied in the Tripos Sybyl 7.3.1 package to carry out flexible docking with 30 conformations for each molecule, using the place particle option as defined by Rarey et al. ${ }^{38}$ We also adjusted the protonation state of "Receptor Descriptor File" residues to both protonated lysine and arginine residues as well as ionized aspartic and glutamic acids residues.

In Vitro HDAC Activity. The relative HDAC-inhibiting potential of each compound was tested against purified HDAC1 and HDAC6. Recombinant FLAG-tagged HDAC1 and HDAC6 were immunopurified from stable expressing cell lines according to previously described procedures. ${ }^{39}$ For inhibition studies, the immunoprecipitated HDACs were washed twice with HDAC buffer (10 mM Tris- $\mathrm{HCl}, \mathrm{pH} 8.0,10 \mathrm{mM} \mathrm{NaCl}$, $10 \%$ glycerol) and preincubated with each inhibitor in HDAC buffer for $30 \mathrm{~min}$ at $4{ }^{\circ} \mathrm{C}$. Beads were resuspended in $30 \mu \mathrm{L}$ of HDAC buffer containing $20000 \mathrm{cpm}$ of a peracetylated $\mathrm{H} 4$ peptide. HDAC activity was determined after incubation for $2 \mathrm{~h}$ at $37^{\circ} \mathrm{C}$. The reaction was stopped by adding $0.04 \mathrm{M}$ acetic acid and $250 \mathrm{mM} \mathrm{HCl}$. The mixture was extracted with ethyl acetate, and the released $\left[{ }^{3} \mathrm{H}\right]$ acetic acid was quantified by scintillation counting.

Note Added after ASAP Publication. This paper was published on March 10, 2010 with an incorrect version of Figure 7. The revised version was published on March 22, 2010.

\section{References}

(1) Kuo, M. H.; Allis, C. D. Roles of histone acetyltransferases and deacetylases in gene regulation. BioEssays 1998, 20, 615-626.

(2) Minucci, S.; Pelicci, P. G. Histone deacetylase inhibitors and the promise of epigenetic (and more) treatments for cancer. Nat. Rev. Cancer 2006, 6, 38-51.

(3) Freiman, R. N.; Tjian, R. Regulating the regulators: lysine modifications make their mark. Cell 2003, 112, 11-17.

(4) Polevoda, B.; Sherman, F. The diversity of acetylated proteins. Genome Biology 2002, 3, Reviews0006.1-0006

(5) Sambucetti, L. C.; Fischer, D. D.; Zabludoff, S.; Kwon, P. O.; Chamberlin, H.; Trogan, N.; Xu, H.; Cohen, D. Histone deacetylase inhibition selectively alters the activity and expression of cell cycle proteins leading to specific chromatin acetylation and antiproliferative effects. J. Biol. Chem. 1999, 274, 34940-34947.

(6) Dokmanovic, M.; Clarke, C.; Marks, P. A. Histone deacetylase inhibitors: overview and perspectives. Mol. Cancer Res. 2007, 5, 981-989. 
(7) Ropero, S.; Esteller, M. The role of histone deacetylases (HDACs) in human cancer. Mol. Oncol. 2007, 1, 19-15.

(8) de Ruijter, A. J.; van Gennip, A. H.; Caron, H. N.; Kemp, S.; van Kuilenburg, A. B. Histone deacetylases (HDACs): characterization of the classical HDAC family. Biochem. J. 2003, 370, 737-749.

(9) Blander, G.; Guarente, L. The Sir2 family of protein deacetylases. Annu. Rev. Biochem. 2004, 73, 417-435.

(10) Marks, P.; Rifkind, R. A.; Richon, V. M.; Breslow, R.; Miller, T.; Kelly, W. K. Histone deacetylases and cancer: causes and therapies. Nat. Rev. Cancer 2001, 1, 194-202.

(11) Richon, V. M.; Webb, Y.; Merger, R.; Sheppard, T.; Jursic, B.; Ngo, L.; Civoli, F.; Breslow, R.; Rifkind, R. A.; Marks, P. A. Second generation hybrid polar compounds are potent inducers of transformed cell differentiation. Proc. Natl. Acad. Sci. U.S.A. 1996, 93, 5705-5708

(12) Al-Janadi, A.; Chandana., S. R.; Cloney, B. A. Histone deacetylase: an attractive target for cancer therapy. Drugs $R \& D .2008,9$, 369-383.

(13) Lane, A. A.; Chabner, B. A. Histone deacetylase inhibitors in cancer therapy. J. Clin Oncol. 2009, 27, 5459-5468.

(14) Liu, T.; Kuljaca, S.; Tee, A.; Marshall, G. M. Histone deacetylase inhibitors: multifunctional anticancer agents. Cancer. Treat. Rev. 2006, 32, 157-165.

(15) Grant, S.; Easley, C.; Kirkpatrick, P. Vorinostat. Nat. Rev. Drug Discovery 2007, 6, 21-22.

(16) Finnin, M. S.; Donigian, J. R.; Cohen, A.; Richon, V. M.; Rifkind, R. A.; Marks, P. A.; Breslow, R.; Pavletich, N. P. Structures of a histone deacetylase homologue bound to the TSA and SAHA inhibitors. Nature 1999, 401, 188-193.

(17) Nielsen, T. K.; Hildmann, C.; Dickmanns, A.; Schwienhorst, A.; Ficner, R. Crystal structure of a bacterial class 2 histone deacetylase homologue. J. Mol. Biol. 2005, 354, 107-120.

(18) Somoza, J. R.; Skene, R. J.; Katz, B. A.; Mol, C.; Ho, J. D.; Jennings, A. J.; Luong, C.; Arvai, A.; Buggy, J. J.; Chi, E.; Tang, J.; Sang, B. C.; Verner, E.; Wynands, R.; Leahy, E. M.; Dougan, D. R.; Snell, G.; Navre, M.; Knuth, M. W.; Swanson, R. V.; McRee, D. E.; Tari, L. W. Structural snapshots of human HDAC8 provide insights into the class I histone deacetylases. Structure 2004, 12, 1325-1334.

(19) Bouchain, G.; Delorme, D. Novel hydroxamate and anilide derivatives as potent histone deacetylase inhibitors: synthesis and antiproliferative evaluation. Curr. Med. Chem. 2003, 10, 23592372.

(20) Nagaoka, Y.; Maeda, T.; Kawai, Y.; Nakashima, D.; Oikawa, T.; Shimoke, K.; Ikeuchi, T.; Kuwajima, H.; Uesato, S. Synthesis and cancer antiproliferative activity of new histone deacetylase inhibitors: hydrophilic hydroxamates and 2-aminobenzamide-containing derivatives. Eur. J. Med. Chem. 2006, 41, 697-708.

(21) Uesato, S.; Kitagawa, M.; Nagaoka, Y.; Maeda, T.; Kuwajima, H.; Yamori, T. Novel histone deacetylase inhibitors: $N$-hydroxycarboxamides possessing a terminal bicyclic aryl group. Bioorg. Med. Chem. Lett. 2002, 12, 1347-1349.

(22) Jung, M.; Brosch, G.; Kolle, D.; Scherf, H.; Gerhauser, C.; Loidl, P. Amide analogues of trichostatin A as inhibitors of histone deacetylase and inducers of terminal cell differentiation. J. Med. Chem. 1999, 42, 4669-4679.

(23) Breslow, R.; Marks, P. A.; Rifkind, R. A.; Jursic, B. Novel Potent Inducers of Terminal Differentiation and Methods Thereof. PTC Int. Appl. WO 93/07148, April 15, 1993.

(24) Stowell, J. C.; Hout, R. I.; Van Voast, L. The synthesis of $N$-hydroxy- $N 1$-phenyloctanediamide and its inhibitory effect on proliferation of AXC rat prostate cancer cells. J. Med. Chem. 1995, 38, 1411-1413.

(25) Mai, A.; Esposito, M.; Sbardella, G.; Massa, S. A new facile and expeditious synthesis of $N$-hydroxy- $N 1$-phenyloctanediamide, a potent inducer of terminal cytodifferentiation. OPPI Briefs 2001, 33, 391-394

(26) Gediya, L. K.; Chopra, P.; Purushottamachar, P.; Maheshwari, N.; Njar, V. C. O. A new simple and high-yield synthesis of suberoyl anilide hydroxamic acid and its inhibitory effect alone or in combination with retinoids on proliferation of human prostate cancer cells. J. Med. Chem. 2005, 48, 5047-5051.

(27) Marks, P. A.; Breslow, R. Dimethyl sulfoxide to vorinostat: development of this histone deacetylase inhibitor as an anticancer drug. Nat. Biotechnol. 2007, 25, 84-90.

(28) Meinke, P. T.; Liberator, P. Histone deacetylase: a target for antiproliferative and antiprotozoal agents. Curr. Med. Chem. 2001, 8, 211-235.

(29) Kozikowski, A. P.; Tapadar, S.; Luchini, D. N.; Hwan, K. K.; Billadeau, D. D. Use of the nitrile oxide cycloaddition (NOC) reaction for molecular probe generation: a new class of enzyme selective histone deacetylase inhibitors (HDACIs) showing picomolar activity at HDAC6. J. Med. Chem. 2008, 51, 4370-4373.

(30) Chen, Y.; Lopez-Sanchez, M.; Savoy, D. N.; Billadeau, D. D.; Dow, G. S.; Kozikowski, A. P. A series of potent and selective, triazolylphenyl-based histone deacetylases inhibitors with activity against pancreatic cancer cells and Plasmodium falciparum. J. Med. Chem. 2008, 51, 3437-3448.

(31) Kozikowski, A. P.; Chen, Y.; Gaysin, A. M.; Savoy, D. N.; Billadeau, D. D.; Kim, K. H. Chemistry, biology, and QSAR studies of substituted biaryl hydroxamates and mercaptoacetamides as HDAC inhibitors-nanomolar potency inhibitors of pancreatic cancer cell growth. ChemMedChem. 2008, 3, 487-501.

(32) Brunel, J. M.; Salmi, C.; Letourneux, Y. Efficient peptide coupling method of conjugated carboxylic acids with methyl ester amino acids hydrochloride. Application to the synthesis of Fa-Met, an important enzymatic substrate. Tetrahedron Lett. 2005, 46, 217-220.

(33) Vannini, A.; Volpari, C.; Filocamo, G.; Casavola, E. C.; Brunetti, M.; Renzoni, D.; Chakravarty, P.; Paolini, C.; De Francesco, R.; Gallinari, P.; Steinkuhler, C.; Di Marco, S. Crystal structure of a eukaryotic zinc-dependent histone deacetylase, human HDAC8, complexed with a hydroxamic acid inhibitor. Proc. Natl. Acad. Sci. U.S.A. 2004, 101, 15064-15069.

(34) Clark, R. D.; Strizhev, A.; Leonard, J. M.; Blake, J. F.; Matthew, J. B. Consensus scoring for ligand/protein interactions. J. Mol. Graphics Modell. 2002, 20, 281-282.

(35) Kramer, B.; Rarey, M.; Lengauer, T. Evaluation of the FLEXX incremental construction algorithm for protein-ligand docking. Proteins 1999, 37, 228-241.

(36) Betzi, S.; Suhre, K.; Chetrit, B.; Guerlesquin, F.; Morelli, X. GFscore: a general nonlinear consensus scoring function for high-throughput docking. J. Chem. Inf. Model. 2006, 46, 1704.

(37) Rarey, M.; Kramer, B.; Lengauer, T.; Klebe, G. A fast flexible docking method using an incremental construction algorithm. J. Mol. Biol. 1996, 261, 470-489.

(38) Rarey, M.; Kramer, B.; Lengauer, T. The particle concept: placing discrete water molecules during protein-ligand docking predictions. Proteins 1999, 34, 17-28.

(39) Fischle, W.; Dequiedt, F.; Hendzel, M. J.; Guenther, M. G.; Lazar, M. A.; Voelter, W.; Verdin, E. Enzymatic activity associated with class II HDACs is dependent on a multiprotein complex containing HDAC3 and SMRT/N-CoR. Mol. Cell 2002, 9, 45-57. 